\title{
Comparing renewable energies: estimating area requirement for biodiesel and photovoltaic solar energy
}

\author{
M. Bravi, F. Coppola, F. Ciampalini \& F. M. Pulselli \\ Department of Chemical and Biosystems Sciences, \\ Siena University, Italy
}

\begin{abstract}
This paper describes two kinds of renewable energy: photovoltaic (PV) solar energy installations connected to the Italian electrical grid system, and pure biodiesel (BD100) production by using sunflower oil. A comparison between them is proposed on the basis of: (A) greenhouse gas emissions (GHG) and (B) land requirement. Point (A) is related to the emissions from carbon dioxide $\left(\mathrm{CO}_{2}\right)$, methane $\left(\mathrm{CH}_{4}\right)$, nitrous oxide $\left(\mathrm{N}_{2} \mathrm{O}\right)$ deriving from energy production and use, which are calculated in terms of $\mathrm{CO}_{2}$ equivalent by their global warming potentials (GWP); point (B) is related to the area (hectares of biomass plantations and $\mathrm{m}^{2}$ of photovoltaic panels) necessary for energy production. The results will be compared to those resulting from the use of fossil fuels.

Keywords: biodiesel, sunflower, photovoltaic, GHG, $\mathrm{CO}_{2}$ equivalent, land requirements, power generation systems.
\end{abstract}

\section{Introduction}

Energy from biomass and photovoltaic (PV) energy systems are two renewable methods to reduce GHG emission, and can contribute to sustainable development. Today about $2.54 \times 10^{13} \mathrm{~kg}$ of $\mathrm{CO}_{2}$ are added to the atmosphere annually [1] because $3 \times 10^{20}$ joules per year of energy depends on coal, oil and natural gas [2]. Incoming solar radiation $\left(5.6 \times 10^{24}\right.$ joules $)$ is far larger than the total demand of energy; from this point of view renewable energies like PVsystem and biomass plantations represent the way to intercept more incoming solar energy. There are two very important limits to the amount of energy that can be obtained from these sources. One is the technological limit due to the 
efficiencies of these energy-converting systems, and the other is connected to the land required to intercept solar radiation. This paper focuses on the second aspect, evaluating energy, $\mathrm{CO}_{2}$ emission and space required for these two kinds of renewable energies with respect to fossil fuels. We compare data on the electricity production from biomass (sunflower production) and PV-system.

The assessment compares a lot of results from various case studies, in order to understand and quantify the environmental impacts.

The ultimate purpose is to evaluate to what extent it is possible to provide renewable energy and avoid emissions under certain conditions. In fact, the electrical power system is one of the most important producers of greenhouse gas $(\mathrm{GHG})$; to reduce them, a strategic approach is:

a) reduce total consumption of energy

b) improve efficiency

c) increase the fraction of renewable energy

These aspects can be evaluated together with other important issues such as:

1) economic and social effects;

2) "ancillary" services required to assure electrical system stability, such as the maintenance of generation/load balance, because some forms of energy generation (photovoltaic and wind) are intermittent and therefore they require a reserve of energy (backup systems) like fossil fuels to compensate demand and supply.

3) The reliability of electrical supply and the size of plants

\section{Methods}

In order to analyse the system of biodiesel production and use, we calculate emission inventory of sunflower cultivation, oilseed transesterification, and its final combustion in engines for electrical power generation. Inventory refers to carbon dioxide $\left(\mathrm{CO}_{2}\right)$, nitrous oxide $\left(\mathrm{N}_{2} \mathrm{O}\right)$, methane $\left(\mathrm{CH}_{4}\right)$, that are converted into $\mathrm{CO}_{2}$ equivalent by their GWP. We also evaluate the entire process from a point of view of land requirement and $\mathrm{CO}_{2}$ equivalent emissions.

The simulation shows four possible steps:

- $\quad$ step a: we quantify the amount of fossil diesel used and the related emissions (industrial production and combustion) per hectare in typical Tuscan farm that produces sunflower;

- $\quad$ step $\boldsymbol{b}$ : we calculate the amount of biodiesel necessary to substitute fossil diesel and the emissions related to its production (data per hectare);

- $\quad$ step $c$ : we calculate the amount of biodiesel necessary to generate electricity in small-scale power generation system and, consequently, land requirement and related emission;

- $\quad$ step $\boldsymbol{d}$ : we calculate greenhouse gas emissions and land requirement of electricity production from biodiesel in tree different cases; the results are then compared with data published in international literature. 
We take up different data set:

- diesel fuel quantities involved in sunflower production come from field data on diesel fuel for each field operation;

- emissions of diesel fuel industrial production are based on data from Danish Life Cycle Assessment (LCA) EDIP Database [3];

- emissions of diesel fuel combustion are calculated by the IPCC method, Energy module [4];

- emissions of biodiesel agricultural production are calculated using IPCC method, Agriculture module [4];

- emissions of biodiesel industrial production are calculated using data from the EU Biofit project [5];

- emissions of biodiesel combustion are calculated from data in the EPA Biodiesel Emissions Database [6].

- We compared our results with the international literature $[7,8]$.

The compared analysis between electrical power production from biodiesel and other generation systems, like photovoltaic, diesel, coal and natural gas is made by using data on $\mathrm{CO}_{2}$ equivalent emissions and energy produced $(\mathrm{kWh})$ for each system, from case studies based on life cycle assessment (LCA). The assessment of these data defines the range of values found in the following international literature:

- emissions per $\mathrm{kWh}$ of electricity produced from diesel, coal and natural gas $[9,10,13]$;

- emissions per kWh of electricity generated from PV technology [1114].

\section{Results}

\subsection{Step A}

To obtain input and output of energy we analyzed sunflower crop production with standards of Life Cycle Analysis methodology. Sunflower seed yield was estimated to vary between 1500 and $2500 \mathrm{~kg} \mathrm{ha}^{-1}[16]$; The yield of raw oil output in seeds crushing process is about $32-38 \%$ [17]. We calculate the yield of biodiesel production for two fixed values: a sunflower seed yield of $2000 \mathrm{~kg} \mathrm{ha}^{-1}$ and an oilseed yield of $35 \%$.

Sunflower cultivation phases, diesel consumption per phase and nitrogen fertilizers requirement are presented in table 1 . These data are an average for a farm of 1000 hectares. The amount of biodiesel necessary to substitute diesel is calculated using the net calorific value of the two fuels, all reported in the same table.

The biodiesel production depends on sunflower oil-seed yield which is connecting to catalysts used for methanolysis during transesterification process. In this case we refer to the study conduced by Vicente et al. [15] who compared different basic catalysts like sodium hydroxide, potassium hydroxide, sodium methoxide, potassium methoxide and each of them has a specific yield of 
biodiesel in the transformation process. The average value among the four catalysts is $94.04 \%$. The biodiesel yield of this plantation in this condition is estimated to be $658 \mathrm{~kg} \mathrm{ha}^{-1}$ year $^{-1}$.

Table 2 shows GHG emissions related diesel fuel used per hectare of sunflower production, considering the total quantity of diesel produced and its combustion. Conversion into $\mathrm{CO}_{2}$ equivalent figures by Global Warming Potential (GWP) are presented too.

Table 1: $\quad$ Fuel quantities and nitrogen fertilizers $\left(\mathrm{kg} \mathrm{ha}^{-1} \mathrm{year}^{-1}\right)$ for sunflower cultivation.

\begin{tabular}{|l|c|c|c|c|c|c|c|}
\hline & Ploughing & Sowing & Fertilization & Pesticide & Harvesting & Transport & Total \\
\hline Diesel & 43 & 10 & 10 & 10 & 20 & 15 & 108 \\
\hline Biodiesel & 49 & 11 & 11 & 11 & 23 & 17 & 124 \\
\hline Fertilizer & & & 200 & & & & 200 \\
\hline
\end{tabular}

Table 2: $\quad$ Emissions $\left(\mathrm{kg} \mathrm{ha}^{-1}\right.$ year $\left.^{-1}\right)$ from diesel and fertilizers use. $\mathrm{N}_{2} \mathrm{O} \mathrm{f}$ is nitrous oxide from fertilizers used for sunflower cultivation, $\mathrm{N}_{2} \mathrm{O} c$ is nitrous oxide from diesel fuel. $\mathrm{CO}_{2}$ equivalent is calculated by GWP.

\begin{tabular}{|l|c|c|c|c|}
\hline & $\mathbf{C O}_{\mathbf{2}}$ & $\mathbf{C H}_{\mathbf{4}}$ & $\mathbf{N}_{\mathbf{2}} \mathbf{O}^{\mathbf{f}}$ & $\mathbf{N}_{\mathbf{2}} \mathbf{O}^{\mathbf{c}}$ \\
\hline Emissions from diesel production & 49.6 & 0.463 & & 0.001 \\
\hline Emissions from diesel combustion & 343 & 0.023 & & 0.003 \\
\hline Total GHG emissions & 392.6 & 0.486 & 2.26 & 0.004 \\
\hline GWP & 1 & 23 & 310 & 310 \\
\hline $\mathrm{CO}_{2}$ eq. & 392.6 & 11.2 & 700.6 & 1.3 \\
\hline Total $\mathrm{CO}_{2}$ eq. & \multicolumn{4}{|c|}{1105.7} \\
\hline
\end{tabular}

\subsection{Step B}

In Table $3 \mathrm{GHG}$ emissions related to biodiesel fuel used per hectare of sunflower production and $\mathrm{CO}_{2}$ equivalent emissions are reported.

Emissions from the industrial process of biodiesel production (transesterification), are based on the EU Biofit 2000 project, in which eight European countries and related research institutes (BLT, Austria; TUD, Denmark; INRA, France; IFEU, Germany; CRES, Greece; CTI, Italy; CLM, The Netherlands; FAT, Switzerland) analyzed production and use of biofuels by an LCA method; biodiesel emissions from combustion are based on the EPA Biodiesel Emissions Database which contains emission test cycles in different engine types. We selected data referred to pure biodiesel (BD100) and the values 
used in our calculations are average values. GHG emissions result from the production process of biodiesel (transesterification), while the net emission of $\mathrm{CO}_{2}$ is considered zero when biodiesel is combusted.

Table 3: $\quad$ Emissions $\left(\mathrm{kg} \mathrm{ha}^{-1}\right.$ year $\left.{ }^{-1}\right)$ from biodiesel and fertilizers use. $\mathrm{N}_{2} \mathrm{O} \frac{\mathbf{f}}{\mathrm{c}}$ is nitrous oxide from fertilizers used for sunflower cultivation, $\mathrm{N}_{2} \mathrm{O}^{-}$ is nitrous oxide from diesel fuel. $\mathrm{CO}_{2}$ equivalent is calculated by GWP.

\begin{tabular}{|l|c|c|c|c|}
\hline & $\mathbf{C O}_{\mathbf{2}}$ & $\mathbf{C H}_{\mathbf{4}}$ & $\mathbf{N}_{\mathbf{2}} \mathbf{O}^{\mathbf{f}}$ & $\mathbf{N}_{\mathbf{2}} \mathbf{O}^{\mathbf{c}}$ \\
\hline Emissions from Biodiesel production & 21.72 & 0.18 & 2.26 & 0.00 \\
\hline Emissions from Biodiesel combustion & 0.00 & 0.00 & 0.00 & 0.01 \\
\hline Total emissions from Biodiesel use & 21.72 & 0.18 & 2.26 & 0.01 \\
\hline $\mathrm{GWP}$ & 1 & 23 & 310 & 310 \\
\hline $\mathrm{CO}_{2}$ eq. & 21.72 & 4.17 & 700.6 & 2.76 \\
\hline Total $\mathrm{CO}_{2}$ eq. & \multicolumn{4}{|c|}{729.25} \\
\hline
\end{tabular}

\subsection{Step C}

The use of biodiesel is also possible in small-scale electricity power generation systems. Power plants from less than $11 \mathrm{kWel}$ up to $1,4 \mathrm{MWel}$ are commercialized in EU [18] and they are considered potentially important markets. Diesel engines are the main mature power technologies with a thermal efficiency between $32.4 \%$ and $36 \%$ [20] with specific-fuel consumption 278.8 $218 \mathrm{~g} / \mathrm{kWh}[17,21]$, when operating on bio-fuels.

On the basis of the characteristics of the farm $(1000$ ha and $658 \mathrm{~kg} \mathrm{ha}^{-1}$ year $^{-1}$ ) we assumed a power plant capacity of $350 \mathrm{kWel}$, with an average consumption of $245 \mathrm{~g} / \mathrm{kWh}$ using diesel and $265 \mathrm{~g} / \mathrm{kWh}$ using biodiesel. The quantity of energy production is about 2483 MWhel per year. In the first year fossil diesel fuel is necessary to start agriculture operations, but in the second year we can consider the farm system self-sufficient using only biodiesel, locally produced, for field operations. In this case (farm of $1000 \mathrm{ha}$ ), the amount of land requirements necessary to substitute diesel is calculated to be 188 ha. At the same time, $\mathrm{CO}_{2}$ equivalent emissions from biodiesel-power plants are $739 \mathrm{~g}$ $\mathrm{CO}_{2}$ eq./KWh for the first year, and $349 \mathrm{~g} \mathrm{CO}_{2} \mathrm{eq} . / \mathrm{KWh}$ for the following years. These emissions are site specific and depend on the production yields. In other words, the amount of biodiesel per unit area can vary depending on different factors: kind of lands, latitude and use of fertilizers and pesticides.

Biodiesel systems generate emissions only the production phase. Fertilizers are the most important emission factors in sunflower production but they are related to agricultural productivity. This means that a reduction of fertilizers is not considered feasible because it would decrease production yields [17].

The results obtained in the analysis, are listed in table 4. 
Table 4: Overview of electrical energy generation system using pure biodiesel product in Siena Province.

\begin{tabular}{|c|c|c|}
\hline Biodiesel yield & $\mathrm{kg} \mathrm{ha}^{-1}$ year $^{-1}$ & 658 \\
\hline Biofuel requirement per unit energy (BD100) & kg/kWel. & 0.265 \\
\hline Efficiency & $\%$ & 36 \\
\hline \multicolumn{3}{|l|}{ First year } \\
\hline Diesel required for field operations & $\mathrm{kg} \mathrm{ha}^{-1}$ year $^{-1}$ & 108 \\
\hline Land use & ha & 1000 \\
\hline Electricity generation & MWh/year & 2483 \\
\hline $\mathrm{CO}_{2}$ equivalent from Diesel for field operation & ton & 1105.7 \\
\hline $\mathrm{CO}_{2}$ equivalent from Biodiesel production & ton & 726.5 \\
\hline $\mathrm{CO}_{2}$ equivalent from Biodiesel combustion & ton & 2.8 \\
\hline Unit $\mathrm{CO}_{2}$ equivalent & $\mathrm{g} / \mathrm{kWhel}$. & 739 \\
\hline Direct land requirements & ha/MWhel. & 0.403 \\
\hline \multicolumn{3}{|l|}{ Second year } \\
\hline Biodiesel required for field operation & $\mathrm{kg} \mathrm{ha}^{-1}$ year $^{-1}$ & 124 \\
\hline Land use & ha & 1188 \\
\hline Electricity generation & MWh/year & 2483 \\
\hline $\begin{array}{l}\mathrm{CO}_{2} \text { equivalent from Biodiesel for field } \\
\text { operation }\end{array}$ & ton & 137 \\
\hline $\mathrm{CO}_{2}$ equivalent from Biodiesel production & ton & 726.5 \\
\hline $\mathrm{CO}_{2}$ equivalent from Biodiesel combustion & ton & 2.8 \\
\hline Unit $\mathrm{CO}_{2}$ equivalent & g/kWhel. & 349 \\
\hline Direct land requirements & ha/MWhel. & 0.479 \\
\hline
\end{tabular}

\subsection{Step D}

Five different kinds of power generation systems are examined: Solar photovoltaic, diesel (oil), coal, natural gas and biodiesel. Typical values of greenhouse gas emissions and land requirement to generate electricity from biodiesel are calculated and compared with data published in case studies; also typical values of fossil fuels and photovoltaic (in terms of emissions of $\mathrm{CO}_{2}$ equivalent) reported by Gagnon et al. [9] are used for comparison. To evaluate land requirement necessary to PV systems installation, we assume that the annual total electricity generated in the central and southern regions of Italy is about $1200 \mathrm{kWh} / \mathrm{KWp}$ per year [22] and electrical energy output from $1 \mathrm{~m}^{2}$ is about $76 \mathrm{kWh}$ per year [23].

In this phase we supposed to produce electrical energy by biodiesel in tree different cases of inputs; for each case we calculate the amount of land use and $\mathrm{CO}_{2}$ equivalent per MWh. Different inputs for sunflower cultivation for each case are reported: 
1) The farm system is fed by diesel fuels and fertilizers (step a);

2) we consider the farm system partially self-sufficient with biodiesel fuel and fertilizers (step b);

3) In this case we suppose the farm system totally self-sufficient with biodiesel fuel and one hypothetical amount of natural fertilizers (zero emissions) as byproduct of sunflower production. In this case, biodiesel yield is reduced and it is estimated at $428 \mathrm{~kg} \mathrm{ha}^{-1}$ year ${ }^{-1}$. Figure 1 show $\mathrm{CO}_{2}$ equivalent requirement to generate energy per MWh.

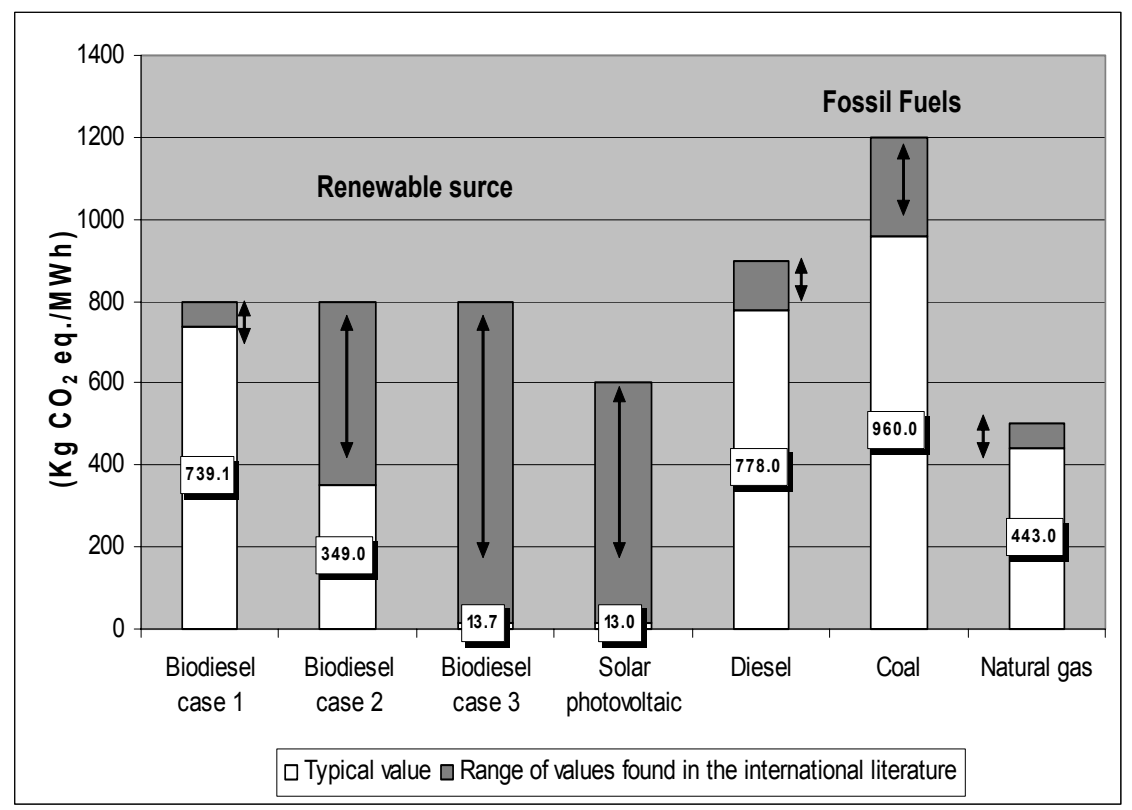

Figure 1: $\quad \mathrm{CO}^{2}$ eq./MWh for power generation systems.

Biodiesel $\mathrm{CO}_{2}$ equivalent emissions could be reduced if input of fossil resources (diesel and fertilizers) are limited. The use of natural fertilizers come out from cattle, fed with residual products of sunflower crop, represents the best option to achieve the target. In this hypothetical condition (case 3) $\mathrm{CO}_{2}$ eq. emissions from biodiesel power plant are $13.7 \mathrm{~kg} \mathrm{CO}_{2}$ eq. $/ \mathrm{MWh}$. In real conditions, emissions related to fertilizers reduce these benefits (case 2) in fact they are $349 \mathrm{~kg} \mathrm{CO}$ eq./MWh. This level is low if compared with emissions from coal, diesel and natural gas, that are 960, 778 and $443 \mathrm{~kg} \mathrm{CO}$ eq. $/ \mathrm{MWh}$ respectively.

Results indicate also (Figure 2) that biodiesel can supply low emissions to produce electrical energy, but it requires 30-40 times more land than photovoltaic system (PV $13 \mathrm{~m}^{2} / \mathrm{MWh}$ per year; biodiesel 403-519 $\mathrm{m}^{2} / \mathrm{MWh}$ per year). Furthermore, Tiezzi [2] expresses the necessity to consider the time of generation and use of resources. Two generations of man have practically depleted resources of coal, oil and natural gas which took thousands of years to 
accumulate. As shown in figure 2, the difference in petroleum diesel and biodiesel is the time of carbon dioxide fixation; in the case of fossil diesel the process occurred in geological time, while for biodiesel carbon dioxide released in atmosphere is fixed in recent years.

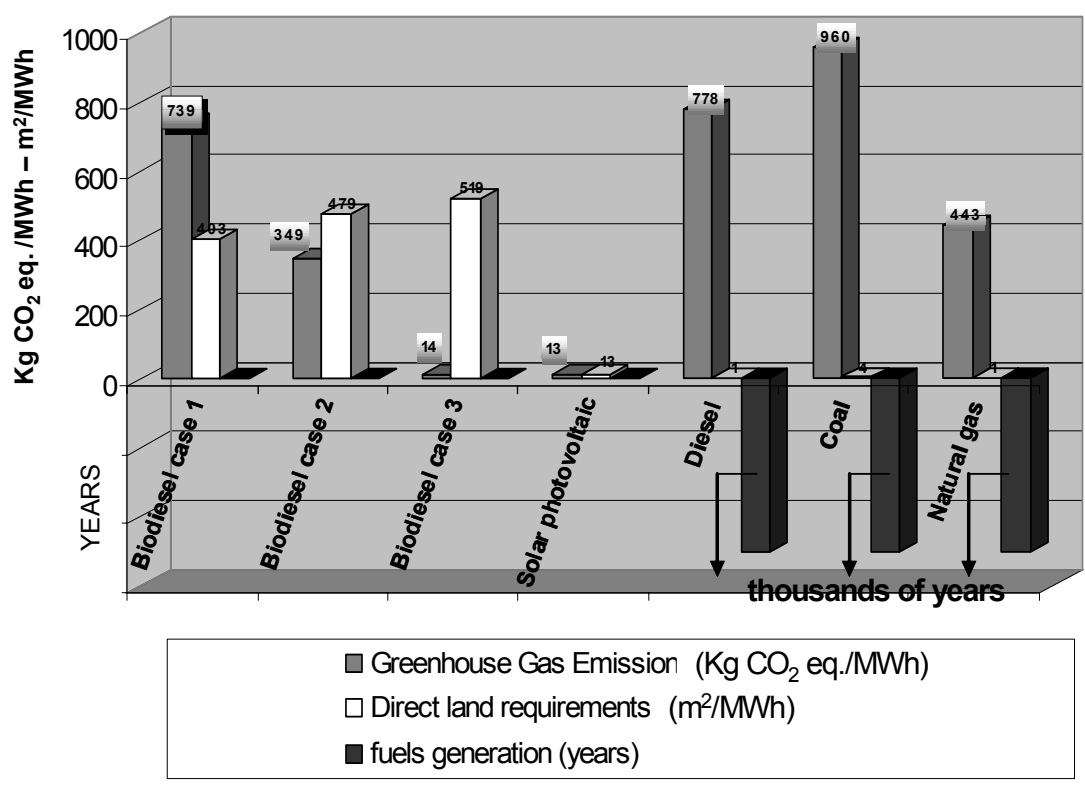

Figure 2: $\quad \mathrm{CO}_{2}$ eq./MWh, time and land requirement, necessary to generate energy.

\section{Conclusions}

Energy saving practices and renewable energies together remain the best way to reduce the dependence from fossil fuels, and they can potentially reduce greenhouse emissions. Biodiesel can supply low emissions to produce electrical energy, but it requires 30-40 times more land than photovoltaic system respect to the estimates yields used (cases 1,2,3). Results indicate also that the use of natural fertilizers come out from cattle, fed with residual products of sunflower crop, could represent the best option to reduce emissions and make totally selfsufficient the farm system.

\section{References}

[1] Energy Information Administration (EIA). International Energy Annual 2003. www.eia.doe.gov/pub/international

[2] Tiezzi, E., The end of time, WIT Press, Southampton, pp. 81, 2003. 
[3] Environmental Design of Industrial Products (EDIP Database), 2006.

[4] Revised IPCC. Guidelines for national green house gas inventory, volumes 1-3. Intergovernmental Panel on Climate Change, London, 1996.

[5] Riva G., Calzoni J., Panvini A., BIOFIT. Bioenergy for Europe: Which one fits best? A comparative analysis for the Community, 2000. Www.cti2000.it

[6] EPA Biodiesel Emission Database (EPA), 2001. www.epa.gov/OMS/models/biodsl

[7] H. Fredriksson, A. Baky, S. Bernesson, Å. Nordberg, O. Norén and P.-A. Hansson, Use of on-farm produced biofuels on organic farms Evaluation of energy balances and environmental loads for three possible fuels, Agricultural Systems, Volume 89, Issue 1, pp. 184-203, July 2006.

[8] Sven Bernesson, Daniel Nilsson and Per-Anders Hansson, A limited LCA comparing large- and small-scale production of rape methyl ester ( $R M E)$ under Swedish conditions, Biomass and Bioenergy, Volume 26, Issue 6, pp. 545-559, June 2004.

[9] Luc Gagnon, Camille Bélanger and Yohji Uchiyama, Life-cycle assessment of electricity generation options: The status of research in year 2001, Energy Policy, Volume 30, Issue 14, pp. 1267-1278, November 2002.

[10] Hiroki Hondo, Life cycle GHG emission analysis of power generation systems: Japanese case, Energy, Volume 30, Issues 11-12, pp. 2042-2056, August-September 2005.

[11] Kazuhiko Kato, Akinobu Murata and Koichi Sakuta, An evaluation on the life cycle of photovoltaic energy system considering production energy of off-grade silicon, Solar Energy Materials and Solar Cells, Volume 47, Issues 1-4, pp. 95-100, October 1997.

[12] Vasilis M. Fthenakis and Hyung Chul Kim, Greenhouse-gas emissions from solar electric- and nuclear power: A life-cycle study, Energy Policy, Volume 35, Issue 4, pp. 2549-2557, April 2007.

[13] Martin Pehnt, Dynamic life cycle assessment (LCA) of renewable energy technologies, Renewable Energy, Volume 31, Issue 1, pp. 55-71 January 2006.

[14] E. A. Alsema and E. Nieuwlaar, Energy viability of photovoltaic systems Energy Policy, Volume 28, Issue 14, pp. 999-1010, November 2000 .

[15] Vicente, G., Martinez, M., Aracil, J., Integrated biodiesel production: a comparison of different homogeneous catalysts systems, Bioresource Technology, 92(3), pp. 297-305, 2004.

[16] Quinto Censimento dell'Agricoltura, Italia, 2000. www.istat.it/censimenti/agricoltura/

[17] Kallivroussis, L., Natsis, A., Papadakis, G., The energy balance of sunflower production for biodiesel in Greece, Biosystems Engineering, 81(3), pp. 347-354, 2002.

[18] ELCOS, energy power systems. www.elcos.net/ITA/elcos-gen-set.html 
[19] David Chiaramonti, Anja Oasmaa and Yrjö Solantausta, Power generation using fast pyrolysis liquids from biomass, Renewable and Sustainable Energy Reviews, Volume 11, Issue 6, pp. 1056-1086, August 2007.

[20] Veli Çelik and Erol Arcaklioğlu, Performance maps of a diesel engine, Applied Energy, Volume 81, Issue 3, pp. 247-259, July 2005.

[21] C. Carraretto, A. Macor, A. Mirandola, A. Stoppato and S. Tonon, Biodiesel as alternative fuel: Experimental analysis and energetice valuations, Energy, Volume 29, Issues 12-15, pp. 2195-2211, OctoberDecember 2004.

[22] Marcel Šúri, Thomas A. Huld, Ewan D. Dunlop and Heinz A. Ossenbrink, Potential of solar electricity generation in the European Union member states and candidate countries, Solar Energy, In Press, Corrected Proof, Available online 14 February 2007.

[23] I. Nawaz and G.N. Tiwari, Embodied energy analysis of photovoltaic (PV) system based on macro- and micro-level, Energy Policy, Volume 34, Issue 17, pp. 3144-3152, November 2006.

[24] International Energy Annual 2004 http://www.eia.doe.gov/iea/pet.html 